\title{
Investigation of Biobutanol Efficiency of Chlorella sp. Cultivated in Municipal Wastewater
}

\author{
Melih Onay \\ Computational \& Experimental Biochemistry Lab., Department of Environmental Engineering, Van Yuzuncu Yil University, Van, \\ Turkey \\ Email: melihonay@yyu.edu.tr
}

How to cite this paper: Onay, M. (2018) Investigation of Biobutanol Efficiency of Chlorella sp. Cultivated in Municipal Wastewater. Journal of Geoscience and Environment Protection, 6, 40-50. https://doi.org/10.4236/gep.2018.610003

Received: September 17, 2018

Accepted: October 20, 2018

Published: October 23, 2018

Copyright $\odot 2018$ by author and Scientific Research Publishing Inc. This work is licensed under the Creative Commons Attribution International License (CC BY 4.0).

http://creativecommons.org/licenses/by/4.0/

\section{c) (i) Open Access}

\begin{abstract}
Many strains of microalgae can grow in wastewaters through their ability to utilize inorganic nitrogen and phosphorus in wastewater. The content of municipal wastewater changes from a location to others. Biofuel production from municipal wastewater has gained huge importance due to progresses in cultivation of microalgae in wastewaters. Biobutanol is produced by the acetone-butanol-ethanol (ABE) fermentation. In this study, we examined the biobutanol production efficiency of Chlorella sp. DEE006 which is cultivated in the municipal wastewater in flat-photobioreactor. Growth of microalgae was monitored at $680 \mathrm{~nm}$ using spectrophotometer and the biomass was also pre-treated with acidic hydrolysis $\left(1 \mathrm{M} \mathrm{H}_{2} \mathrm{SO}_{4}\right)$. Total carbohydrate and protein contents were measured. Fermented microalgae samples were taken for calculation of biobutanol concentration. We obtained both high biobutanol content $\left(6.23 \pm 0.19 \mathrm{~g} \cdot \mathrm{L}^{-1}\right)$ and high bioethanol yield $0.16 \pm 0.005 \mathrm{~g}$ (g sugar $)^{-1} .50 \%$ wastewater had the highest biomass concentration $(1930 \pm 11$ $\mathrm{mg} / \mathrm{L}$ ) among the wastewaters with five various concentrations. It had the highest biomass productivity with $0.28 \pm 0.001 \mathrm{~g} \mathrm{~L}^{-1} \mathrm{~d}^{-1}$. Also, it obtained the highest carbohydrate and protein concentration with $0.80 \pm 0.02 \mathrm{gL}^{-1}$ and $0.95 \pm 0.01 \mathrm{gL}^{-1}$, respectively. According to our results, Chlorella sp. DEE006 can be used for large scale biobutanol production in the future.
\end{abstract}

\section{Keywords}

Microalgae, Chlorella, Biobutanol, Biofuel, Municipal Wastewater

\section{Introduction}

Biofuel is a renewable energy resource and it has gained great importance in re- 
cent years because of depletion of fossil fuel. Biobutanol is a kind of biofuel and it $\left(\mathrm{C}_{4} \mathrm{H}_{9} \mathrm{OH}\right)$ has four carbons including colourless alcohol. It is used as solvent, organic synthesis and extractant [1]. Biobutanol has several advantages compare to other biofuels. Biobutanol is more advantageous than bioethanol and biomethanol due to its energy density and similarity to gasoline. It can be used in fuel engines as a blend with diesel without any modification. Biobutanol has half the heat of vaporization of that of ethanol. This property is important for engine initiation at sub-zero temperatures. In addition, biobutanol has a lower vapour pressure and lower volatility. This maintains more effective storage and transport [2] [3]. Microalgae are third generation biofuels and they have superior properties compare to first and second generation biofuel. Microalgae have no competition with agricultural crops for land needed. They can grow fast and generate huge amount of biomass. Also, conversion technology of microalgae to biomass has simple structural properties compared to second generation biofuel [4] [5]. Biobutanol is produced by the acetone-butanol-ethanol (ABE) fermentation. In this process, microalgal biomass is used as a substrate. Generally, $C$. acetobutylicum is selected for anaerobic digestion [3]. It produces butyric and acetic acids through a process called acidogenesis, followed by solventogenesis, where butanol, acetone and ethanol are synthesized. Biomass has to have rich carbohydrate content for effective biobutanol production. Starch which is storage component of carbohydrate is located in plastids in microalgae. Moreover, cellulose, the cell wall component of microalgae, contributes carbohydrate content in microalgae [2] [6]. Production of acetate and butyrate reduce the culture $\mathrm{pH}$ and it causes to solvent production. This reaction results in an acetone, butanol and ethanol ratio of 3:6:1 [7]. Microalgae are basically useful to decrease the concentration of inorganic nitrogen and phosphorus in the wastewaters. Many strains of microalgae can grow in the wastewaters through their ability to utilize inorganic nitrogen and phosphorus in the wastewater. Thus, cultures of microalgae are useful for wastewater treatment as a tertiary process [8]. Developing of urbanization and increasing of urban population led to huge amount of municipal wastewater. The content of municipal wastewater changes from a location to others. It includes organic wastes, human wastes, nutrients and household chemicals. Compared with industrial and agricultural wastewater, there is less nitrogen and phosphorus in municipal wastewater [9]. Biofuel production from municipal wastewater has gained huge importance due to progress in cultivation of microalgae in wastewaters. Chlorophytes is one of the largest phyla of microalgae. These microalgae have been displayed to be potential used to a variety of wastewater conditions and very efficiency at nutrients removal from wastewater. Chlorella species have been carried out for removing of nitrogen and phosphorus from wastewaters in detail [10]. Chlorella species maintain a high nutrient pollutions removal and depleted in municipal wastewater [11].

In this study, we examined the biobutanol production efficiency of Chlorella sp. DEE006 which is cultivated in municipal wastewater in flat-photobioreactor. 


\section{Materials and Methods}

\subsection{Microalgae Strain and Cultivation}

Microalgae were obtained from YYU-microalgae collection. Chlorella sp. DEE006 was cultured at $25^{\circ} \mathrm{C} \pm 2{ }^{\circ} \mathrm{C}$ and Bold's Basal Medium (BBM) was prepared with some modifications according to Andersen, 2005 [12]. BBM was adjusted to $\mathrm{pH} 6.8$ and checked for control experiments. The municipal wastewater was autoclaved and mixed with Bold's Basal Medium (BBM) before using. The batch cultures of Chlorella sp. DEE006 were grown at different ratios (v/v) of municipal wastewater $(0 \%, 25 \%, 50 \%, 75 \%$ and $100 \%$ wastewater). Municipal wastewater was obtained from Van, Turkey. The microbial contamination was checked with Thoma cell counting chamber and maintained less than $2 \%$ when increasing contamination (up to $2 \%$ ). More than $2 \%$ can lead to bacterial and fungal contamination and this situation can adversely affect growth curves of microalgae.

\subsection{Design of Photobioreactor}

In this study, batch culture studies were examined in $500 \mathrm{~mL}$ of Erlenmeyer flasks consisting of $250 \mathrm{~mL}$ of medium. For continuous studies, we designed flat airlift photobioreactor (PBR) $(1 \mathrm{~L})$ and air was injected at the bottom for culture mixing with a constant air flow rate of $0.3 \mathrm{~L} \cdot \mathrm{min}^{-1}$. PBR was illuminated with an external light source at a light intensity of approximately $180 \mu \mathrm{mol} \mathrm{m}^{-2} \mathrm{~s}^{-1}$. Before using, PBR was sterilised $30 \mathrm{~min}$ with a $5 \mathrm{mM}$ peroxyacetic acid solution.

\subsection{Growth Evaluation and Harvesting of Microalgae}

Growth of microalgae was monitored at $680 \mathrm{~nm}$ using spectrophotometer. Ash free dry weights (AFDW) were obtained for correlation between optical density and dry weight. The algal suspension was grown up to stationary growth phase and harvested by centrifugation at $3000 \mathrm{~g}$ for $10 \mathrm{~min}$ at $4 \mathrm{C}$ according to Barsanti and Gualtieri [13]. The algal biomass was lyophilized and stored at $-20^{\circ} \mathrm{C}$ for further analysis. All experiments were performed with three biological replicates.

\subsection{Specific Growth Rate Calculation}

Specific growth rates of microalgal biomass were calculated by the following equation [14]. Specific growth rate $(\mu)$ : In $\left(X_{1}-X_{2}\right) /\left(t_{2}-t_{1}\right)$. Where, $X_{1}$ : Biomass concentration at the end of the selected time interval in $\mathrm{mg} \cdot \mathrm{L}^{-1} ; \mathrm{X}_{2}$ : biomass concentration at the beginning of the selected time interval in $\mathrm{mg} \cdot \mathrm{L}^{-1} ; \mathrm{t}_{2}-\mathrm{t}_{1}$ : Time elapsed between the selected time points in days (d). The doubling time was calculated with using Equation below.

$$
T_{d}=0.693 / \mu
$$

\subsection{Acid Treatment Procedure}

Biomass was also treated with acidic hydrolysis $\left(1 \mathrm{M} \mathrm{H}_{2} \mathrm{SO}_{4}\right)$. Samples were au- 
toclaved at $121^{\circ} \mathrm{C}$ for $30 \mathrm{~min}$. After hydrolysis, samples were cooled down to room temperature and suspension was centrifuged at $4000 \mathrm{~g}$ for $10 \mathrm{~min}$. The supernatant was taken for sugar content analysis.

\subsection{Determination of Total Protein Concentration}

Total protein was extracted according to Weis et al., 2002 [15]. Protein concentration of the isolates was calculated according to the Bradford method [16]. Bovine serum albumin (BSA) was used as standard. Absorbance values were measured at $595 \mathrm{~nm}$.

\subsection{Determination of Total Carbohydrate Concentration}

Total carbohydrate contents of the isolates were determined by the anthrone method with minor modifications [17]. Glucose was used as a standard at various concentrations $(10,40,60,100,150,200 \mu \mathrm{g} / \mathrm{mL})$.

\subsection{Fermentation of Microalgal Biomass}

C. acetobutylicum was selected for biobutanol fermentation. The growth medium of $C$. acetobutylicum included 1 - $40 \mathrm{~g}$ of glucose or microalgae biomass, $0.17 \mathrm{~g}$ of $\mathrm{KH}_{2} \mathrm{PO}_{4}, 0.16 \mathrm{~g}$ of $\mathrm{Na}_{2} \mathrm{SO}_{4}, 5 \mathrm{~g}$ of yeast extract, 1 of tryptone, $0.01 \mathrm{~g}$ of $\mathrm{p}$-aminobenzoic acid and $0.01 \mathrm{~g}$ of Biotin with $\mathrm{pH}$ adjusted to 4.8 . The butanol fermentation was carried out at $37^{\circ} \mathrm{C}$.

\subsection{Fermentation of Microalgal Biomass}

Fermented microalgae samples were taken for calculation of biobutanol concentration. Biobutanol concentrations were measured according to Maiti et al., 2015 [18] spectrophotometrically. All experiments were performed with three biological replicates.

\section{Results and Discussion}

\subsection{General Observations about Municipal Wastewater}

In this study, the municipal wastewater was sterilized and the microbial contamination was checked with Thoma cell counting chamber and maintained less than $2 \%$. Throughout our study, municipal wastewater and BBM were mixed proportionally $(0 \%, 25 \%, 50 \%, 75 \%$ and $100 \%)$.

\subsection{Evaluation of Growth Curves of Microalgae Grown in Municipal Wastewater}

Growth curves of microalgae can change in various mediums and stress conditions. In this study, we plotted growth curves of microalgae grown in different concentrations $(0 \%, 25 \%, 50 \%, 75 \%$ and $100 \%)$ of municipal wastewater. Control group includes components of BBM and shown as $0 \%$. But, $100 \%$ wastewater consists of completely municipal wastewater. Growth curves were plotted via 
absorbance values and biomass concentrations versus time (days). The results were given in Figure 1. 50\% wastewater displayed the fastest growth (1.49 \pm 0.002), reaching stationary phase for growth at nine days. Control, $25 \%, 75 \%$ and $100 \%$ of wastewater reached to stationary phase between six and nine days with different absorbance values $1.29 \pm 0.001,1.46 \pm 0.001,1.32 \pm 0.001,0.94 \pm$ 0.001 , respectively. The efficient growth of microalgae in wastewater is dependent on many reasons such as the types and the sources of wastewater. Also, the variation is also displayed in the tolerant capacities of various microalga species to specific wastewater conditions [10]. According to literature, our results were similar. Many microalgae strain can be grown in municipal wastewater and they can deplete nitrogen, phosphorus and sulphur until reaching stationary phase. Thus, biomass of microalgae can be applied for wastewater treatment and biofuel production [8] [19].

According to biomass concentrations, microalgae had linearity when cell number and optical density were plotted versus time (days). 50\% wastewater had the highest biomass concentration $(1930 \pm 11 \mathrm{mg} / \mathrm{L})$ among wastewater with five various concentrations. $25 \%$ wastewater showed higher biomass concentration $(1789 \pm 11 \mathrm{mg} / \mathrm{L})$ than those of control $(1556 \pm 11 \mathrm{mg} / \mathrm{L})$ and $75 \%$ wastewater $(1567 \pm 19 \mathrm{mg} / \mathrm{L})$. Also, $100 \%$ wastewater displayed the lowest biomass concentration with $(1122 \pm 22 \mathrm{mg} / \mathrm{L})$. The results were shown in Figure 2. These results are support by Cai et al., 2013 [20]. In this study, they show that growth of microalgae, biomass content and lipid production change significantly in wastewater [20]. Cho et al., 2013 also carried out that Chlorella sp. yield the highest biomass production nearly $3.0 \mathrm{~g} \cdot \mathrm{L}^{-1}$ with $10 \%$ anaerobic digestion tanks, and conflux line of the $90 \%$ wastewaters combined wastewater as nutrients for microalgae cultivation [21].

Biomass productivity of Chlorella sp. DEE06 grown in different concentrations of wastewater was calculated according to their maximum biomass concentrations. $50 \%$ wastewater had the highest biomass productivity with $0.28 \pm$ $0.001 \mathrm{~g} \mathrm{~L}^{-1} \mathrm{~d}^{-1} .25 \%$ wastewater reached to higher stationary phase than control group and $75 \%$ wastewater. It showed higher biomass productivity $(0.26 \pm 0.002$ $\left.\mathrm{g} \mathrm{L}^{-1} \mathrm{~d}^{-1}\right)$ than those of control $\left(0.22 \pm 0.004 \mathrm{~g} \mathrm{~L}^{-1} \mathrm{~d}^{-1}\right)$ and $75 \%(0.22 \pm 0.002 \mathrm{~g}$ $\left.\mathrm{L}^{-1} \mathrm{~d}^{-1}\right) .100 \%$ wastewater had the lowest biomass productivity $(0.19 \pm 0.003 \mathrm{~g}$ $\left.\mathrm{L}^{-1} \mathrm{~d}^{-1}\right)$. In addition, we calculated specific growth rates of microalgae in different wastewater concentrations.

$50 \%$ wastewater showed maximum specific growth rate $\left(5.98 \pm 0.01 \mathrm{~d}^{-1}\right)$ when compared to control, $25 \%, 75 \%$ and $100 \% .100 \%$ wastewater had minimum specific growth rate $\left(5.55 \pm 0.02 \mathrm{~d}^{-1}\right)$. Also, control, $25 \%, 50 \%, 75 \%$ and $100 \%$ wastewater had $0.120 \mathrm{~d}, 0.121 \mathrm{~d}, 0.116 \mathrm{~d}, 0.119 \mathrm{~d}$ and $0.125 \mathrm{~d}$, respectively. The results were given in Table 1. The total nitrogen and total phosphorus can fluctuate in medium according to types of wastewater. Some of studies indicated that municipal, agricultural and industrial wastewaters for Chlorella species can cause changes of biomass content and productivity [1] [9] [22] [23]. 


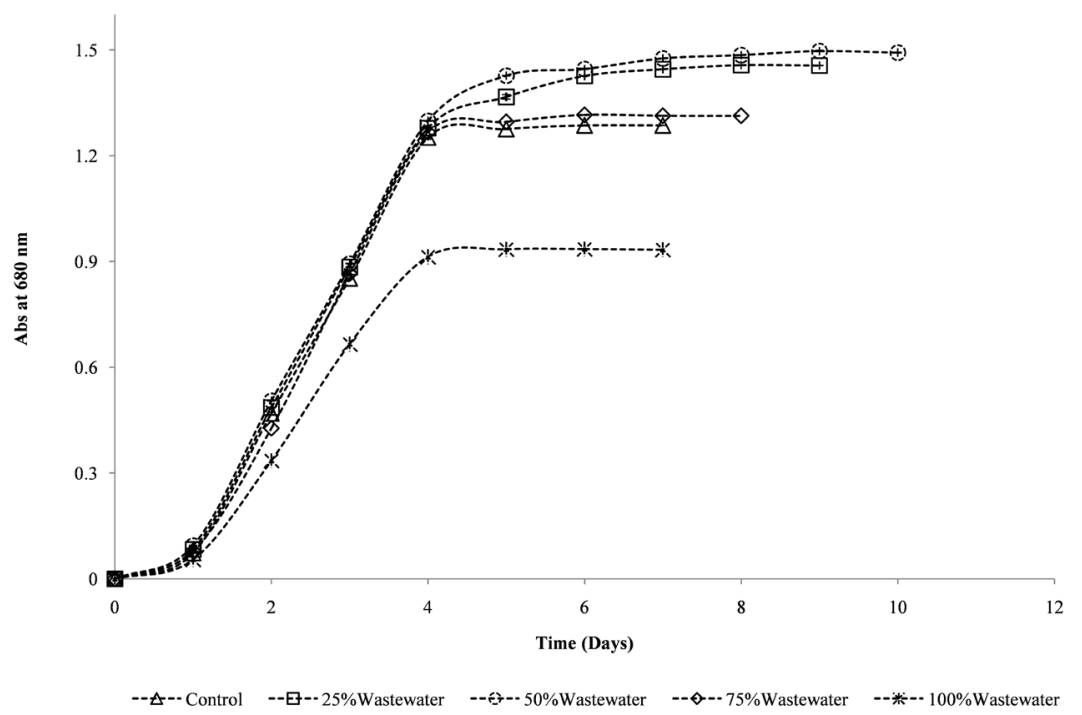

Figure 1. Growth curves of Chlorella sp. DEE006 cultivated in various concentrations of municipal wastewateras a function of absorbance values at $680 \mathrm{nmvs}$ time (days).

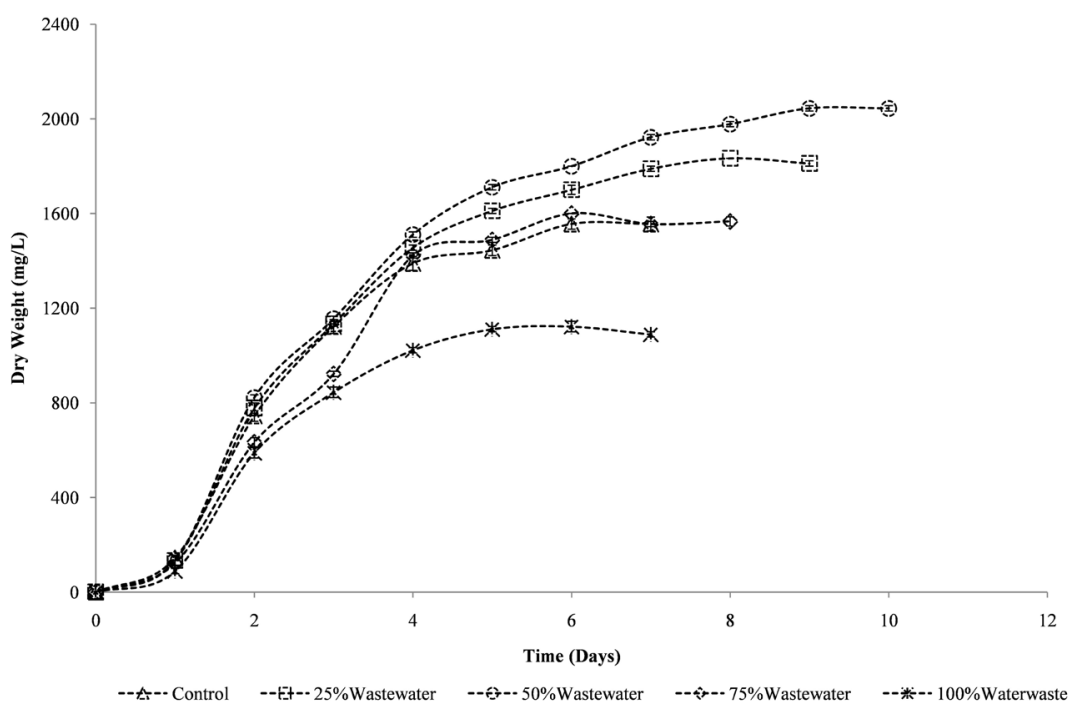

Figure 2. Growth curves of Chlorella sp. DEE006 cultivated in various concentrations of municipal wastewater as a function of dry weight $(\mathrm{mg} / \mathrm{L})$ at $680 \mathrm{nmvs}$ time (days).

Table 1. Biomass concentrations, biomass productivities, specific growth rates and doubling time of Chlorella sp. DEE006 cultivated in various concentrations of municipal wastewater.

\begin{tabular}{ccccc}
\hline $\begin{array}{c}\text { Wastewater } \\
\text { concentrations }\end{array}$ & $\begin{array}{c}\text { Biomass concentrations } \\
\left(\mathrm{g} \cdot \mathrm{L}^{-1}\right)\end{array}$ & $\begin{array}{c}\text { Biomass productivity } \\
\left(\mathrm{g} \mathrm{L}^{-1} \mathrm{~d}^{-1}\right)\end{array}$ & $\begin{array}{c}\text { Specific growth } \\
\text { rate }(\mu)\left(\mathrm{d}^{-1}\right)\end{array}$ & $\begin{array}{c}\text { Doubling } \\
\text { Time }(\mathrm{d})\end{array}$ \\
\hline Control & $1.56 \pm 0.03$ & $0.22 \pm 0.004$ & $5.78 \pm 0.01$ & 0.120 \\
$25 \%$ wastewater & $1.79 \pm 0.01$ & $0.26 \pm 0.002$ & $5.75 \pm 0.01$ & 0.121 \\
$50 \%$ wastewater & $1.93 \pm 0.01$ & $0.28 \pm 0.001$ & $5.98 \pm 0.01$ & 0.116 \\
$75 \%$ wastewater & $1.56 \pm 0.01$ & $0.22 \pm 0.002$ & $5.83 \pm 0.01$ & 0.119 \\
$100 \%$ wastewater & $1.12 \pm 0.02$ & $0.19 \pm 0.003$ & $5.55 \pm 0.02$ & 0.125 \\
\hline
\end{tabular}




\subsection{Carbohydrate and Protein Contents of Microalgae Grown in Municipal Wastewater}

We plotted carbohydrate and protein concentration of Chlorella sp. DEE006 grown in municipal wastewater according to $\mathrm{gL}^{-1}$ versus time (day). $50 \%$ wastewater had the highest carbohydrate concentration $\left(0.80 \pm 0.02 \mathrm{gL}^{-1}\right)$ on the stationary phase. $25 \%, 75 \%$ and $100 \%$ showed lower carbohydrate contents with $0.66 \pm 0.01 \mathrm{gL}^{-1}, 0.52 \pm 0.01 \mathrm{gL}^{-1}$ and $0.37 \pm 0.01 \mathrm{gL}^{-1}$, respectively. In addition, protein contents of Chlorella sp. DEE006 were plotted and 50\% wastewater had the highest protein content $\left(0.95 \pm 0.01 \mathrm{gL}^{-1}\right)$ among other wastewater concentrations. $25 \%$ wastewater $\left(0.85 \pm 0.01 \mathrm{gL}^{-1}\right)$ showed the higher protein content than those of $75 \%\left(0.71 \pm 0.01 \mathrm{gL}^{-1}\right)$ and $100 \%\left(0.50 \pm 0.01 \mathrm{gL}^{-1}\right)$. The results were displayed in Figure 3.

These results show parallel to literature. The current studies focused on increasing the biomass and lipid yield of microalgae [24]. Lipid content of microalgae grown in wastewater was not determined in a few studies. Lipid contents of microalgae were lower than $10 \mathrm{mg} \mathrm{L}^{-1} \mathrm{~d}^{-1}$ (10\%) [25]. This can cause much more carbohydrate and protein accumulation. Wang et al. (2010) carried out Chlorella sp. on anaerobically digested dairy manure. The total fatty acid content ranged from $9.0 \%$ to $13.7 \% \mathrm{DW}\left(0.141-0.233 \mathrm{~g} \cdot \mathrm{L}^{-1}\right)$ depending on the wastewater concentration used [1]. We calculated maximum carbohydrate and protein concentrations of microalgae grown in various municipal wastewaters. The highest carbohydrate content was $39.9 \% \pm 1.2 \%$ at $50 \%$ wastewater. $25 \%$ wastewater showed the lower carbohydrate contents $(35.8 \% \pm 0.7 \%)$. Control, $75 \%$ and $100 \%$ wastewater had similar carbohydrate contents with $33.8 \% \pm 0.9 \%, 33.4 \% \pm$ $0.2 \%$ and $33.5 \% \pm 0.5 \%$, respectively. In addition, $25 \%$ and $50 \%$ wastewater accumulated similar protein contents, $46.2 \% \pm 0.7 \%$ and $46.4 \% \pm 0.2 \%$ respectively. Control, $75 \%$ and $100 \%$ had lower protein contents, $45 \% \pm 2.1 \%, 45.2 \% \pm$ $0.7 \%$ and $44.2 \% \pm 1.2 \%$, respectively. Carbohydrate and protein contents were given in Table 2.

\subsection{Biobutanol Production}

C. acetobutylicum was used for biobutanol fermentation. Initial sugar concentrations $(1,2,5,10,20$ and $40 \mathrm{~g})$ were adjusted and glucouse was used for standard. Because Chlorella sp.DEE006 grown in \% 50 wastewater has the highest biomass productivity and carbohydrate content, it was selected for biobutanol production. Biobutanol content found as $6.23 \pm 0.19 \mathrm{~g} \cdot \mathrm{L}^{-1}$. In addition to this, we carried out its bioethanol yield and it was $0.16 \pm 0.005 \mathrm{~g}$ (g sugar) ${ }^{-1}$. The results were given in Table 3. In the literature, scientific articles related with biobutanol production from microalgae are not enough for evaluation of biofuel on microalgae. Many studies focused on biodiesel production. Yang studied the effects of water usage and life cycle water for biodiesel production and determined nutrients usage of microalgae in this system [26]. Wang examined enhancing bio-butanol production from biomass of Chlorella vulgaris JSC- 6 with sequential 
Table 2. Carbohydrate, protein, lipid and biomass concentrations of Chlorella sp. $D E E 006$ cultivated in various concentrations of municipal wastewater.

\begin{tabular}{ccccc}
\hline $\begin{array}{c}\text { Wastewater } \\
\text { concentrations }\end{array}$ & $\begin{array}{c}\text { Carbohydrate } \\
(\mathrm{dwt} \%)\end{array}$ & $\begin{array}{c}\text { Protein } \\
(\mathrm{dwt} \%)\end{array}$ & $\begin{array}{c}\text { Lipid } \\
(\mathrm{dwt})\end{array}$ & $\begin{array}{c}\text { Biomass concentrations } \\
\left(\mathrm{g} \cdot \mathrm{L}^{-1}\right)\end{array}$ \\
\hline Control & $33.8 \pm 0.9$ & $45 \pm 2.1$ & N.D. & $1.56 \pm 0.03$ \\
$25 \%$ wastewater & $35.8 \pm 0.7$ & $46.2 \pm 0.7$ & N.D. & $1.79 \pm 0.01$ \\
$50 \%$ wastewater & $39.9 \pm 1.2$ & $46.4 \pm 0.2$ & N.D. & $1.93 \pm 0.01$ \\
$75 \%$ wastewater & $33.4 \pm 0.2$ & $45.2 \pm 0.7$ & N.D. & $1.56 \pm 0.01$ \\
$100 \%$ wastewater & $33.5 \pm 0.5$ & $44.2 \pm 1.2$ & N.D. & $1.12 \pm 0.02$ \\
\hline
\end{tabular}

Table 3. Biobutanol content $(\mathrm{g} / \mathrm{L})$ and Biobutanol yield (g/g sugar) of Chlorella sp. DEE006 cultivated in 50\% concentration of municipal wastewater.

\begin{tabular}{cccc}
\hline $\begin{array}{c}\text { Wastewater } \\
\text { concentration }\end{array}$ & $\begin{array}{c}\text { Initial sugar } \\
\text { concentration }(\mathrm{g} / \mathrm{L})\end{array}$ & $\begin{array}{c}\text { Biobutanol content } \\
(\mathrm{g} / \mathrm{L})\end{array}$ & $\begin{array}{c}\text { Biobutanol } \\
\text { Yield (g/g sugar) }\end{array}$ \\
\hline $50 \%$ wastewater & 40 & $6.23 \pm 0.19$ & $0.16 \pm 0.005$ \\
\hline
\end{tabular}

(a)
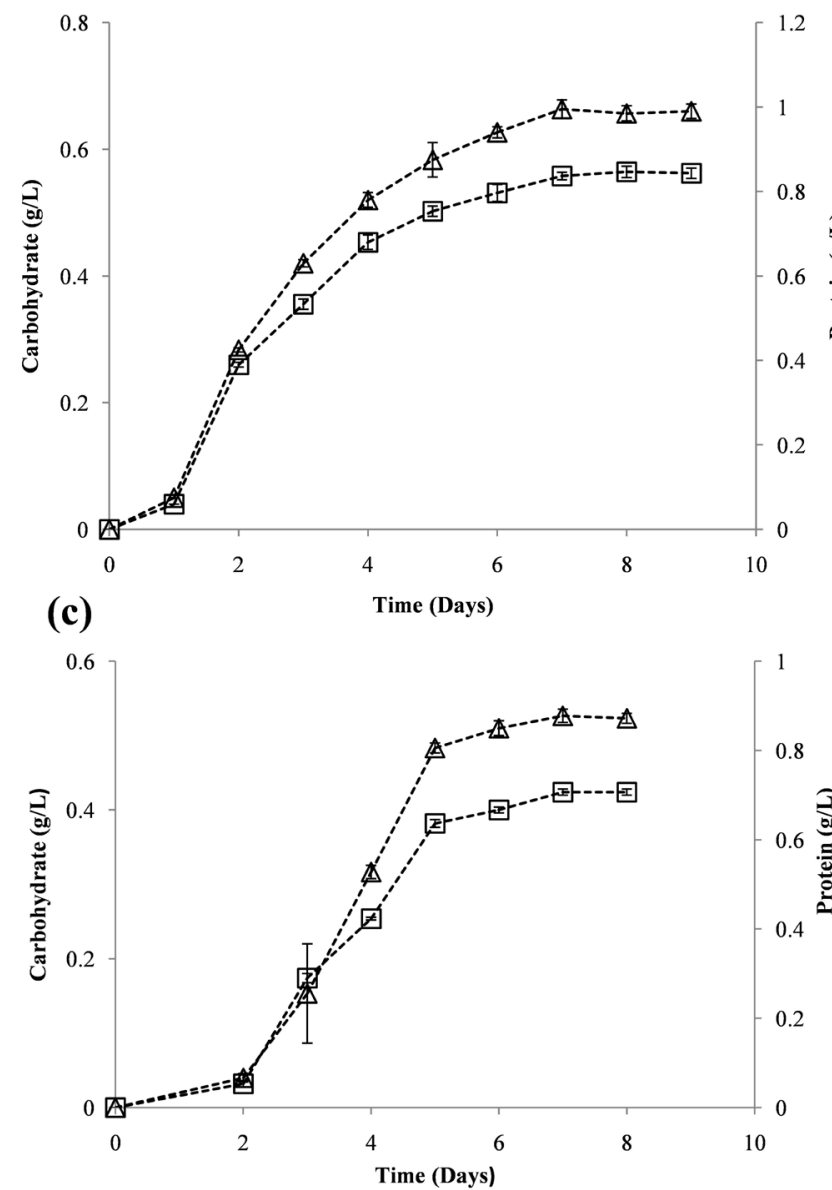

(b)
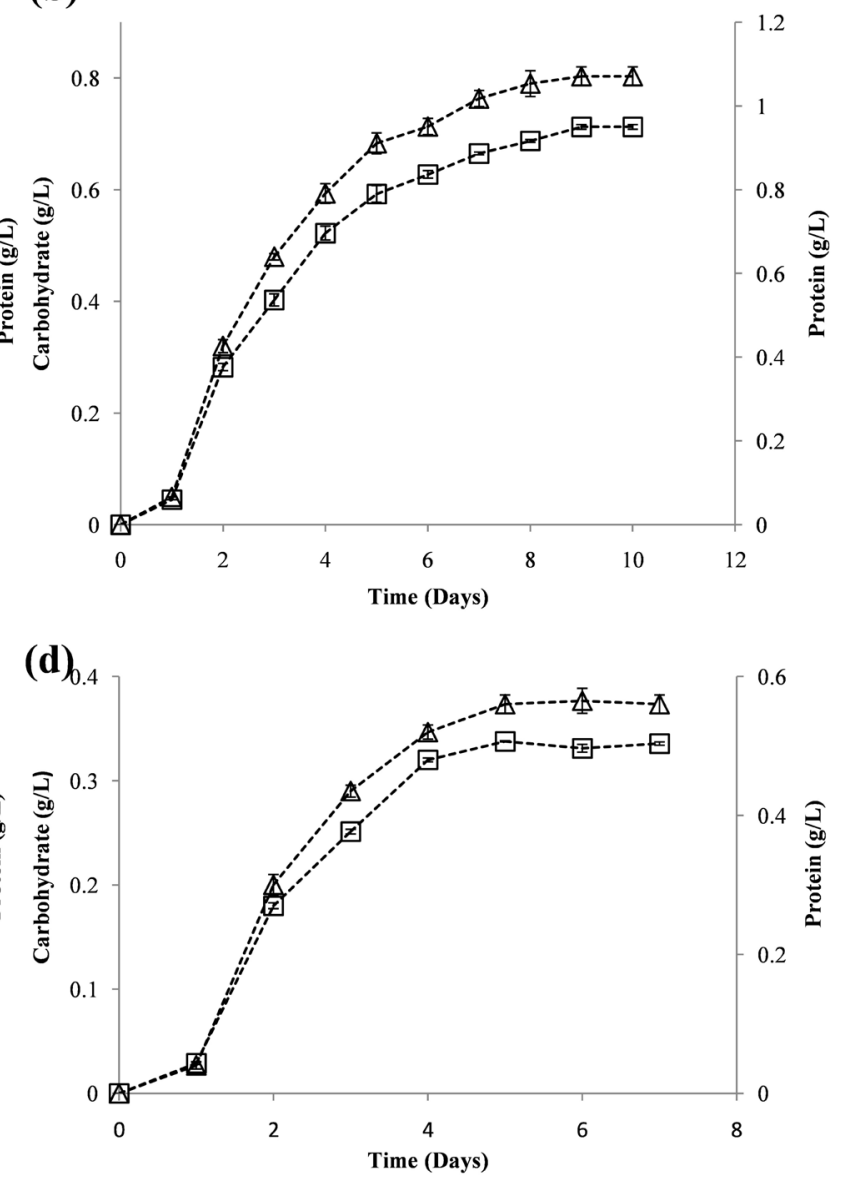

Figure 3. Curves of carbohydrate and protein contents of Chlorella sp. DEE006 cultivated in various concentrations of municipal wastewater as a factor of dry weight ( $\mathrm{gL}^{-1}$ ) versus time (days). (a) $25 \%$, (b) $50 \%$, (c) $75 \%$ (d) $100 \%$ of wastewater concentrations. Carbohydrate and protein content were shown as triangular and square in the figures, respectively. 
alkali pretreatment and acid hydrolysis and found that the optimal $\mathrm{NaOH}$ and $\mathrm{H}_{2} \mathrm{SO}_{4}$ concentrations used for the pretreatment were $1 \%$ and $3 \%(\mathrm{w} / \mathrm{v})$, respectively for high bio-butanol production [27].

\section{Conclusion}

The biobutanol production efficiency of Chlorella sp. DEE006 which is cultivated in municipal wastewater in flat-photobioreactor was carried out in the present study. They gave the various days because microalgae reached to stationary phase in the different days. Various concentrations of wastewater affect stationary phases and give different biomass concentration. We obtained both high biobutanol content $\left(6.23 \pm 0.19 \mathrm{~g} \cdot \mathrm{L}^{-1}\right)$ and high bioethanol yield $0.16 \pm 0.005 \mathrm{~g}(\mathrm{~g}$ sugar $^{-1}$. 50\% wastewater had the highest biomass concentration $(1930 \pm 11$ $\mathrm{mg} / \mathrm{L}$ ) among wastewater with five various concentrations. It had the highest biomass productivity with $0.28 \pm 0.001 \mathrm{~g} \mathrm{~L}^{-1} \mathrm{~d}^{-1}$. Also, it obtained the highest carbohydrate and protein concentration with $0.80 \pm 0.02 \mathrm{gL}^{-1}$ and $0.95 \pm 0.01$ $\mathrm{gL}^{-1}$, respectively. According to our results, Chlorella sp. DEE006 can be used for large scale biobutanol production in the future.

\section{Acknowledgements}

Author would like to thank Van-YYU-Department of Environmental Engineering for technical support. Also, this work was supported by Van-YYU-BAP. Author thanks the financial support of project, YYU-BAP-FAP-2017-6218.

\section{Conflicts of Interest}

The author declares no conflicts of interest regarding the publication of this paper.

\section{References}

[1] Wang, L., Li, Y., Chen, P., Min, M., Chen, Y., Zhu, J. and Ruan, R.R. (2010) Anaerobic Digested Dairy Manure as a Nutrient Supplement for Cultivation of Oil-Rich Green Microalgae Chlorellla sp. Bioresource Technology, 101, 2623-2628. https://doi.org/10.1016/j.biortech.2009.10.062

[2] Yeong, T.K., Jiao, K., Zeng, X., Lin, L., Pan, S. and Danquah, M.K. (2018) Microalgae for Biobutanol Production-Technology Evaluation and Value Proposition. Algal Research, 31, 367-376. https://doi.org/10.1016/j.algal.2018.02.029

[3] Lee, S.Y., Park, J.H., Jang, S.H., Nielsen, L.K., Kim, J. and Jung, K.S. (2008). Fermentative Butanol Production by Clostridia. Biotechnology and Bioengineering, 101, 209-228. https://doi.org/10.1002/bit.22003

[4] Berni, M.D., Dorileo, I. L., Prado, J.M., Cameiro, T.F. and Meireles, M.A.A. (2013) Advances in Biofuel Production. Biofuels Production. 1st Edition, Wiley Online Library, 11-58. https://doi.org/10.1002/9781118835913.ch2

[5] Harun, R., Singh, M., Forde G.M. and Danquah, M.K. (2010) Bioprocess Engineering of Microalgae to Produce a Variety of Consumer Products. Renewable \& Sus tainable Energy Reviews, 14, 1037-1047. https://doi.org/10.1016/j.rser.2009.11.004 
[6] Inui, M., Suda, M., Kimura, S., Yasuda, K., Suziki, H., Toda, H., Yamamoto, S., Okino, S., Suziki, N. and Yukawa, H. (2008) Expression of Clostridium acetobutylicum Butanol Synthetic Genes in Escherichia coli. Applied Microbiology and Biotechnology, 77, 1305-1316. https://doi.org/10.1007/s00253-007-1257-5

[7] Ranjan, A. and Moholkar, V.S. (2012) Biobutanol: Science, Engineering, and Economics. International Journal of Energy Research, 36, 277-323. https://doi.org/10.1002/er.1948

[8] Martin, C., De la Noüe, J. and Picard, G. (1985) Intensive Culture of Freshwater Microalgae on Aerated Pig Manure. Biomass, 7, 245-259. https://doi.org/10.1016/0144-4565(85)90064-2

[9] Li, Y., Chen, Y.F., Chen, P., Min, M., Zhou, W., Martinez, B., Zhub, J. and Ruan, R. (2011) Characterization of a Microalga Chlorella sp. Well Adapted to Highly Concentrated Municipal Wastewater for Nutrient Removal and Biodiesel Production. Bioresource Technology, 102, 5138-5144. https://doi.org/10.1016/j.biortech.2011.01.091

[10] Chiu, S.Y., Kao, C., Chen , T., Chang, Y., Kuo, C. and Lin, C. (2015) Cultivation of Microalgal Chlorella for Biomass and Lipid Production Using Wastewater as $\mathrm{Nu}$ trient Resource. Bioresource Technology, 184, 179-189. https://doi.org/10.1016/j.biortech.2014.11.080

[11] Lau, P.S., Tam, N.F.Y. and Wong, Y.S. (1996) Wastewater Nutrients Removal by Chlorella vulgaris. Optimization through Acclimation. Environmental Technology, 17, 183-189. https://doi.org/10.1080/09593331708616375

[12] Andersen, RA. (2005) Algal Culturing Techniques. 1st Edition. Elsevier Academic press, USA.

[13] Barsanti, L. and Gualtieri, P. (2006) Algae Anatomy Biochemistry and Biotechnology. CRC Press, Raton.

[14] Onay, M., Sonmez, C., Oktem, H.A. and Yucel, A.M. (2014) Thermo-Resistant Green Microalgae for Effective Biodiesel Production: Isolation and Characterization of Unialgal Species from Geothermal Flora of Central Anatolia. Bioresource Technology, 169, 62-71. https://doi.org/10.1016/j.biortech.2014.06.078

[15] Weis, V.M., Verde, E.A. and Reynolds, W.S. (2002) Characterization of a Short Form Perdinin Chlorophyll-Protein (PCP) cDNA and Protein from the Symbiotic Dinoflagellate Symbiodinium muscatinei (Dinophyceae) from the Sea Anemone Anthopleura elegantissima. Journal of Phycology, 38, 157-163. https://doi.org/10.1046/j.1529-8817.2002.01132.x

[16] Bradford, M.M. (1976) A Rapid and Sensitive Method for the Quantitation of Microgram Quantities of Protein Utilizing the Principle of Protein Dye Binding. Analitical Biochemistry, 72, 248-254. https://doi.org/10.1016/0003-2697(76)90527-3

[17] Zhao, G., Chen, X., Wang, L., Zhou, S., Feng, H., Chen, W.N. and Lau, R. (2013) Ultrasound Assisted Extraction of Carbohydrates from Microalgae as Feedstock for Yeast Fermentation. Bioresource Technology, 128, 337-344. https://doi.org/10.1016/j.biortech.2012.10.038

[18] Maiti, S., Sarma, S.J., Brar, S.K., Le Bihan, Y., Drogui, P., Buelna, G., Verma, M. and Soccol, C.R. (2015) Novel Spectrophotometric Method for Detection and Estimation of Butanol in Acetone-Butanol-Ethanol Fermenter. Talanta, 141, 116-121. https://doi.org/10.1016/j.talanta.2015.03.062

[19] Ahluwalia, S.S. and Goyal, D. (2007) Microbial and Plant Derived Biomass for Removal of Heavy Metals from Wastewater. Bioresource Technology, 98, 2243-2257. 
https://doi.org/10.1016/j.biortech.2005.12.006

[20] Cai, T., Park, S.Y. and Li, Y. (2013) Nutrient Recovery from Wastewater Streams by Microalgae: Status and Prospects. Renewable and Sustainable Energy Reviews, 19, 360-369. https://doi.org/10.1016/j.rser.2012.11.030

[21] Cho, S., Lee, N., Park, S., Yu, J., Luong, T.T., Oh, Y.K. and Lee, T. (2013) Microalgae Cultivation for Bioenergy Production Using Wastewaters from a Municipal WWTP as Nutritional Sources. Bioresource Technology, 131, 515-520. https://doi.org/10.1016/j.biortech.2012.12.176

[22] Zhu, L., Wang, Z., Shu, Q., Takala, J., Hiltunen, E., Feng, P. and Yuan, Z. (2013) Nutrient Removal and Biodiesel Production by Integration of Freshwater Algae Cultivation with Piggery Wastewater Treatment. Water Research, 47, 4294-4302. https://doi.org/10.1016/j.watres.2013.05.004

[23] Sun, X., Sun, X., Wang, C., Li, Z., Wang, W., Tong, Y. and Wei, J. (2013) Microalgal Cultivation in Wastewater from the Fermentation Effluent in Riboflavin (B2) Manufacturing for Biodiesel Production. Bioresource Technology, 143, 499-504. https://doi.org/10.1016/j.biortech.2013.06.044

[24] Onay, M., Sonmez, C., Oktem, H.A. and Yucel, A.M. (2016) Evaluation of Various Extraction Techniques for Efficient Lipid Recovery from Thermo-Resistant Microalgae, Hindakia, scenedesmus and Micractinium Species. American Journal of Analytical Chemistry, 7, 141-150. https://doi.org/10.4236/ajac.2016.72012

[25] Wu, Y.H., Hu, H.Y., Yu, Y., Zhang, T.Y., Zhu, S.F., Zhuang, L.L., Zhang, X. and Lu, Y. (2014) Microalgal Species for Sustainable Biomass Lipid Production Using Wastewater as Resource. Renewable and Sustainable Energy Reviews, 33, 675-688. https://doi.org/10.1016/j.rser.2014.02.026

[26] Yang, J., Li, X., Hu, H.Y., Zhang, X., Yu, Y. and Chen, Y.S. (2011) Growth and Lipid Accumulation Properties of a Freshwater Microalga, Chlorella ellipsoidea $Y$ I in Domestic Secondary Effluents. Applied Energy, 88, 3295-3299. https://doi.org/10.1016/j.apenergy.2010.11.029

[27] Wang, Y., Guo, W., Cheng, C., Ho, S., Chang, J. and Ren, N. (2016) Enhancing Bio-Butanol Production from Biomass of Chlorella vulgaris JSC-6 with Sequential Alkali Pre-Treatment and Acid Hydrolysis. Bioresource Technology, 200, 557-564. https://doi.org/10.1016/j.biortech.2015.10.056 